\title{
Effect of Sucrose Concentrations and Incubation Periods on in Vitro Rooting of Moris Pineapple (Ananas comosus)
}

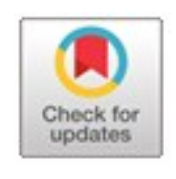

\author{
Abdelhamid M Hamad \\ Department of Horticulture, Faculty of Agriculture, Omar Al Mukhtar University, Al-Bayda, Libya
}

Received: 19 July 2018/ Accepted: 1 December 2019

Doi: https://doi.org/10.54172/mjsc.v34i4.145

\begin{abstract}
The effect of 6 sucrose concentrations (5, 10, 15, 20, 25, $30 \mathrm{~g} / 1)$ over 4 incubation periods $(30,45,60,75$ days) on in vitro rooting of Moris pineapple cultured in liquid half strength MS medium enriched with IBA at $2.0 \mathrm{mg} / \mathrm{l}$ was investigated. At all incubation periods, all shoots in medium enriched with sucrose at $5 \mathrm{~g} / 1$ failed to root, and no roots formed within the first 30 days in medium enriched with sucrose at $10 \mathrm{~g} / \mathrm{l}$. After 30 days of incubation, the highest rooting percentage (66\%), tallest plantlets (23 $\mathrm{mm}$ tall), highest (3.4 roots) and longest $(5.3 \mathrm{~mm})$ root per shoot were obtained in medium enriched with sucrose at $25,10,15,15 \mathrm{~g} / 1$ respectively, while after 45 days, the highest of all rooting aspects $(75 \%, 32.3 \mathrm{~mm}$ tall, 3.7 roots, $7 \mathrm{~mm}$ long), were obtained in medium enriched with sucrose at $15 \mathrm{~g} / \mathrm{l}$. After 60 days, the highest rooting percentage $(91.7 \%)$ and tallest plantlets $(36.7 \mathrm{~mm}$ tall) were obtained in medium enriched with sucrose at $20 \mathrm{~g} / 1$ while highest roots per shoot (3.7 roots) and longest root $(10.7 \mathrm{~mm})$ were obtained in medium enriched with sucrose at $15 \mathrm{~g} / \mathrm{l}$. After 75 days, all shoots rooted $(100 \%)$ in medium enriched with sucrose at 10 and $20 \mathrm{~g} / 1$, while sucrose at $25 \mathrm{~g} / 1$ resulted in tallest plantlets $(46.3 \mathrm{~mm}$ tall) and at $20 \mathrm{~g} / 1$ resulted in highest (4.7 roots) and longest roots $(27.3 \mathrm{~mm})$. At each incubation period, there was a different optimum sucrose enrichment for different rooting parameters.
\end{abstract}

Key words: Sucrose; Incubation Periods; In Vitro Rooting; Moris Pineapple; Ananas comosus.

\section{INTRODUCTION}

Different combinations of sucrose and incubation periods were used for the in vitro rooting of pineapple. In vitro rooting was reported using sucrose at $10 \mathrm{~g} / 1$ and incubation for 30 days and 70 days (Soneji et al., 2002b), sucrose at $20 \mathrm{~g} / 1$ for 30 days (Ko et al., 2006; Mengesha et al., 2013; Souza et al., 2016; Sunitibala Devi et al., 1997) and 70 days (Soneji et al., 2002b), sucrose at $30 \mathrm{~g} / 1$ for 30 days (Almeida et al., 2002; Aydieh et al., 2000; Bhatia \& Ashwath, 2000; Fitchet, 1990; Singh \& Manual, 2000; Teng, 1997), 45 (Khan et al., 2004; Sripaoraya et al., 2003), 60 (Gangopadhyay et al., 2005; Hamad et al., 2013; Mathews \& Rangan, 1979, 1981) and 75 days (Hamad \& Taha, 2008) and sucrose at $35 \mathrm{~g} / 1$ for 30 days (Kofi \& Adachi,
1993 ) and sucrose at $40 \mathrm{~g} / 1$ for 60 days of incubation (De Almeida et al., 1997). In all of these studies, each of the sucrose and incubation periods was fixed at one level and the focus was on hormone types and concentrations and medium strength. The effect of different sucrose concentrations and incubation periods were neither compared individually nor in combinations of the two factors. In addition, many times the results were reported as a general statement or the rooting response was assessed based only on one parameter, rooting percentage (Bhatia \& Ashwath, 2000), root number (Danso et al., 2008). In some cases, two parameters, root number and length (Aydieh et al., 2000; Khatun et al., 1997) and in few cases, three parameters: rooting percent-

*Corresponding Author: Abdelhamid M Hamad abdelhamidhamad@gmail.com, Department of Horticulture, Faculty of Agriculture, Omar Al Mukhtar University, Al-Bayda, Libya. 
age, root number, and length (Amin et al., 2005; Soneji et al., 2002a), were used for the assessment of rooting treatments. The plantlets' height, on the other hand, was rarely reported (Be \& Debergh, 2006; Hamad et al., 2013; Souza et al., 2016). Sucrose and incubation period are not only important for its effect on rooting, but also for their effect on cost and management of the rooting stage and plantlets survival of acclimatization. Sucrose made the highest proportion of the medium components. And for the incubation period, lamps and air conditioning is required to maintain constant temperature and photoperiod. In large scale propagation, using higher sucrose and longer incubation would make the medium cost and electricity bill too expensive. Using the lowest possible concentration of sucrose and the shortest incubation period would reduce the cost of rooting stage and the overall cost of propagules production. The objective of this study is to compare the effect of different sucrose concentrations over different incubation periods on all rooting aspects of Moris pineapple cultivar. And to determine the best compromise of lowest possible concentration and shortest incubation period at which the best rooting responses, particularly the plantlets' height, could be obtained. The goal is to minimize the cost in terms of the sucrose amount and monthly electricity bill per single propagule.

\section{MATERIALS AND METHODS}

A half-strength MS medium $(450 \mathrm{ml})$ enriched with IBA at $2.0 \mathrm{mg} / 1$ (Murashige and Skoog, 1962) was prepared and divided into 6 glass jars (75 ml each) marked 1 to 6. Sucrose at 5, 10, 15, 20, 25 and $30 \mathrm{~g} / 1$ were added to each glass jar respectively. The medium was adjusted to $\mathrm{pH}$ 5.0 and autoclaved at $121^{0} \mathrm{C}$ and $1.5 \mathrm{~kg} / \mathrm{cm}^{2}$ for 20 minutes. The content of each glass jar was dispensed into 12 culture tubes (6 ml each) under a laminar cabinet using a sterilized syringe and the tubes marked with the same glass jar mark. Shoots from Moris pineapple stock cultures were cultured at a density of five shoots per culture. The cultures were incubated under constant temperature $\left(25^{\circ} \mathrm{C}\right)$ and 16 hours of light provided by fluorescent lamps for 30, 45, 60 and 75 days. After 30 days of incubation, three culture tubes of each sucrose concentration were taken for data collection. The shoots were picked out to count the number of rooted shoots, number of roots per shoot, and to measure the roots length and plantlet height. A table for each rooting parameter of the different sucrose concentrations with three replicates was established and named the 30 days incubation tables. After 45, 60 and 75 days, three culture tubes of each sucrose concentration were taken out of the culture room, and a table for each rooting parameter of the different sucrose concentrations at each incubation period was established as were done after 30 days incubation. The tables of the same parameter obtained after different incubation periods (30, 45, 60 and 75 days) were combined in one table containing all combinations of sucrose and incubation periods and used for the analysis of variance and testing the significance of means by Duncan Multiple Range Test at $\mathrm{p} \leq 0.05$ using SPSS statistical package No.11.

\section{RESULTS}

Two-way analysis of variance (Table 1) showed that both of the sucrose and incubation periods had a significant effect on all in vitro rooting aspects of pineapple. However, the sucrose seemed to have a higher influence on rooting percentage, root number, and length than the incubation period, while incubation periods affected plantlets' height more than the sucrose. The two factors exerted their influence independently from each other except in root length, where a significant interaction was detected at $\mathrm{p}$ $<0.055$. Overall sucrose concentrations, incubation for 30 and 45 days, had statistically an equal effect in root formation (2 roots), elongation $(4 \mathrm{~mm})$ and plantlets height $(24 \mathrm{~mm})$ but the rooting percentage increased from 32 to 43.1 $\%$ as the incubation increased from 30 to 45 days (Table 2). Incubation for 60 days resulted in intermediate responses where $55.6 \%$ of the shoots rooted, forming 2.5 roots/shoots, $6.7 \mathrm{~mm}$ long roots, and the plantlets reached $31.7 \mathrm{~mm}$ in 
height. Incubation for 75 days, on the other hand, $(76.4 \%)$, more roots per shoot (3.1 roots), longest roots $(12.1 \mathrm{~mm}$ long), and tallest plantlets $(39.17 \mathrm{~mm})$. Similarly, across all incubation periods, none of the shoots cultured on MS enriched with sucrose at $5 \mathrm{~g} / 1$ produced roots, and the plantlets were the shortest $(20.1 \mathrm{~mm}$ tall $)$ of all sucrose concentrations. No significant difference between the plantlets' height in media enriched with sucrose at 10,15, 20, 25, and $30 \mathrm{~g} / 1$ (31.3 $\mathrm{mm}$ on average). In medium enriched with sucrose at $10 \mathrm{~g} / 1,35.4 \%$ of the shoots rooted, forming 1.5 roots per shoot each $5.5 \mathrm{~mm}$ long, and the plantlets were $30.1 \mathrm{~mm}$ tall. No significant difference in rooting percentage in media enriched with sucrose at $15,20,25$, and $30 \mathrm{~g} / 1$ (68.75\% on average). Medium enriched with sucrose at $15 \mathrm{~g} / 1$ resulted in highest root formation (3.8 roots) and medium enriched with sucrose at $10 \mathrm{~g} / \mathrm{l}$ resulted in fewest roots $(1.5$ roots), while intermediate root formation (3 roots) was obtained in a media enriched with sucrose at 20 and $25 \mathrm{~g} / 1$. Medium enriched with sucrose at $20 \mathrm{~g} / 1$ resulted in longest roots (11.5 $\mathrm{mm})$ and those enriched with sucrose at 10 and $30 \mathrm{~g} / 1$ resulted in shortest roots $(5.4 \mathrm{~mm})$, while intermediate root length $(8.4 \mathrm{~mm})$ obtained in media enriched with sucrose at 15 and $25 \mathrm{~g} / \mathrm{l}$.

Under 30 days of incubation, none of the shoots rooted in medium enriched with sucrose at 5 and $10 \mathrm{~g} / \mathrm{l}$ and the plantlets were the shortest (15.7 $\mathrm{mm}$ ) compared to plantlets rooted in the other sucrose concentrations $(22.3 \mathrm{~mm})$. The highest rooting percentage $(67 \%)$ was obtained in medium enriched with sucrose at $25 \mathrm{~g} / \mathrm{l}$ while the highest roots per shoot (3.4 roots) and longest roots (5.3 $\mathrm{mm}$ ) were obtained in medium enriched with sucrose at $15 \mathrm{~g} / \mathrm{l}$. For 30 days incubation, the best sucrose enrichment was $25 \mathrm{~g} / 1$ according to rooting percentage and $15 \mathrm{~g} / 1$ according to the other parameters (root per shoot, root length, and plantlet height). Under 45 days of incubation also none of the shoots rooted in medium enriched with 5 $\mathrm{g} / \mathrm{l}$. The highest rooting percentage $(75 \%)$, roots per shoot (4 roots) and longest roots $(7 \mathrm{~mm})$ were obtained in medium-enriched with sucrose at 15 $\mathrm{g} / 1$ and the tallest plantlets $(32.3 \mathrm{~mm})$ were obtained in medium enriched with sucrose at 20 and $15 \mathrm{~g} / \mathrm{l}$ while medium enriched with sucrose at 5 $\mathrm{g} / \mathrm{l}$ resulted in the shortest plantlets $(19 \mathrm{~mm})$ and a medium enriched with sucrose at $10 \mathrm{~g} / 1$ resulted in the lowest rooting percentage $(16.7 \%)$, fewest roots per shoot (1 root) and shortest roots (1.7 $\mathrm{mm})$. For 45 days incubation, the best sucrose enrichment was $15 \mathrm{~g} / 1$ according to all parameters. Under 60 days of incubation, none of the shoots rooted in medium enriched with $5 \mathrm{~g} / \mathrm{l}$. The highest rooting percentage $(91.7 \%)$, roots per shoot (4 roots), and tallest plantlets $(36.7 \mathrm{~mm})$ were obtained in medium enriched with $20 \mathrm{~g} / \mathrm{l}$ and the longest roots $(11.7 \mathrm{~mm})$ were obtained in medium enriched with sucrose at $25 \mathrm{~g} / 1$.

Table (1). Significant of main and interaction effect of incubation periods and sucrose concentrations on in vitro rooting response of Moris pineapple cultures on a liquid half-strength medium enriched with IBA at $2.0 \mathrm{mg} / \mathrm{l}$.

\begin{tabular}{lcllll}
\hline \hline \multirow{2}{*}{ Factors } & df & \multicolumn{4}{l}{ Rooting parameters } \\
& & Plantlet height & Rooting \% & Root No. & Root length \\
\hline & & & & & \\
Incubation periods & 3 & $6.4 \mathrm{E}-08^{* *}$ & $9.8 \mathrm{E}-06^{* *}$ & $0.0500^{*}$ & $0.0002^{* *}$ \\
Sucrose & 5 & $0.0015^{* *}$ & $2.3 \mathrm{E}-10^{* *}$ & $7.3 \mathrm{E}-07^{* *}$ & $7.5 \mathrm{E}-05^{* *}$ \\
Incubation*Sucrose & 15 & 0.8063 & 0.0879 & 0.4769 & $0.0054^{* *}$ \\
Error & 48 & & & & \\
Total & 72 & & & & \\
\hline \hline
\end{tabular}


Table (2). Effect of incubation periods and sucrose concentrations on in vitro rooting of Moris pineapple cultured on liquid half-strength MS medium enriched with IBA at $2.0 \mathrm{mg} / \mathrm{l}$

\begin{tabular}{|c|c|c|c|c|c|c|c|}
\hline \multicolumn{3}{|c|}{ Incubation periods } & \multicolumn{3}{|c|}{ Sucrose concentrations (g/l) } & \multirow{2}{*}{\multicolumn{2}{|c|}{ Average }} \\
\hline (Days) & 5 & 10 & 15 & 25 & & & \\
\hline \multicolumn{8}{|c|}{ Plantlet height (mm) } \\
\hline 30 & $15.7 \mathrm{~h}$ & 23.0 defgh & 21.7 defgh & 22.3 defgh & 20.3 efgh & 22.0 defgh & $20.8 \mathrm{C}$ \\
\hline 45 & $19.0 \mathrm{gh}$ & $28.0 \mathrm{cdefgh}$ & 32.3 abcdefg & 31.3 abcdefg & $19.7 \mathrm{fgh}$ & 25.7 defgh & $26.0 \mathrm{C}$ \\
\hline 60 & 21.3 defgh & $34.0 \mathrm{abcdefg}$ & 36.0 abcde & $36.7 \mathrm{abcd}$ & 29.7 bcdefgh & 32.7 abcdefg & $31.7 \mathrm{~B}$ \\
\hline 75 & 24.3 defgh & 35.3 abcdef & $43.0 \mathrm{abc}$ & $43.7 \mathrm{ab}$ & $46.3 \mathrm{a}$ & $42.3 \mathrm{abc}$ & $39.17 \mathrm{~A}$ \\
\hline Average & $20.1 \mathrm{~B}$ & $30.1 \mathrm{~A}$ & $33.3 \mathrm{~A}$ & $33.5 \mathrm{~A}$ & $29.0 \mathrm{~A}$ & $30.7 \mathrm{~A}$ & \\
\hline \multicolumn{8}{|c|}{ Rooting \% } \\
\hline 30 & $0.0 \mathrm{f}$ & $0.0 \mathrm{f}$ & 50 bcde & 41.7 cdef & 66.7 abcd & 33.3 cdef & $32.0 \mathrm{D}$ \\
\hline 45 & $0.0 \mathrm{f}$ & $16.7 \mathrm{ef}$ & $75 \mathrm{abc}$ & 50 bcde & $66.7 \mathrm{abcd}$ & 50 bcde & $43.1 \mathrm{C}$ \\
\hline 60 & $0.0 \mathrm{f}$ & $25 \mathrm{def}$ & $75 \mathrm{abc}$ & $91.7 \mathrm{ab}$ & $75 a b c$ & $66.7 \mathrm{abcd}$ & $55.6 \mathrm{~B}$ \\
\hline 75 & $0.0 \mathrm{f}$ & $100 \mathrm{a}$ & $91.7 \mathrm{ab}$ & $100 \mathrm{a}$ & $91.7 \mathrm{ab}$ & $75 \mathrm{abc}$ & $76.4 \mathrm{~A}$ \\
\hline Average & $0.0 \mathrm{C}$ & $35.4 \mathrm{~B}$ & $72.9 \mathrm{~A}$ & $70.8 \mathrm{~A}$ & $75.0 \mathrm{~A}$ & $56.3 \mathrm{~A}$ & \\
\hline \multicolumn{8}{|l|}{ Root No. } \\
\hline 30 & $0.0 \mathrm{~d}$ & $0.0 \mathrm{~d}$ & $3.4 \mathrm{abc}$ & $1.7 \mathrm{bcd}$ & $2.7 \mathrm{abcd}$ & $2.3 \mathrm{abcd}$ & $1.7 \mathrm{~B}$ \\
\hline 45 & $0.0 \mathrm{~d}$ & $1 \mathrm{~cd}$ & $3.7 \mathrm{abc}$ & $2.0 \mathrm{abcd}$ & $2.7 \mathrm{abcd}$ & $2.3 \mathrm{abcd}$ & $2.0 \mathrm{~B}$ \\
\hline 60 & $0.0 \mathrm{~d}$ & $1 \mathrm{~cd}$ & $4.0 \mathrm{ab}$ & $4 \mathrm{ab}$ & $3.3 \mathrm{abc}$ & $2.7 \mathrm{abcd}$ & $2.5 \mathrm{AB}$ \\
\hline 75 & $0.0 \mathrm{~d}$ & $4 \mathrm{ab}$ & $4.3 \mathrm{ab}$ & $4.7 \mathrm{a}$ & $3 \mathrm{abc}$ & $2.7 \mathrm{abcd}$ & $3.1 \mathrm{~A}$ \\
\hline Average & $0.0 \mathrm{D}$ & $1.5 \mathrm{C}$ & $3.8 \mathrm{~A}$ & $3.1 \mathrm{AB}$ & $2.9 \mathrm{AB}$ & $2.5 \mathrm{BC}$ & \\
\hline \multicolumn{8}{|c|}{ Root length (mm) } \\
\hline 30 & $0.0 \mathrm{~d}$ & $0.0 \mathrm{~d}$ & $5.3 \mathrm{~cd}$ & $3.7 \mathrm{~cd}$ & $6 \mathrm{~cd}$ & $3.0 \mathrm{~cd}$ & $3.0 \mathrm{~B}$ \\
\hline 45 & $0.0 \mathrm{~d}$ & $1.7 \mathrm{~cd}$ & $7 \mathrm{bcd}$ & $5.7 \mathrm{~cd}$ & $5.3 \mathrm{~cd}$ & $5.7 \mathrm{~cd}$ & $4.2 \mathrm{~B}$ \\
\hline 60 & $0.0 \mathrm{~d}$ & $4.3 \mathrm{~cd}$ & $10.7 \mathrm{bc}$ & $9.3 \mathrm{bcd}$ & $11.7 \mathrm{bc}$ & $4.7 \mathrm{~cd}$ & $6.8 \mathrm{~B}$ \\
\hline 75 & $0.0 \mathrm{~d}$ & $16 \mathrm{~b}$ & $10.3 \mathrm{bcd}$ & $27.3 \mathrm{a}$ & $10.7 \mathrm{bc}$ & $8.0 \mathrm{bcd}$ & $12.1 \mathrm{~A}$ \\
\hline Average & $0.0 \mathrm{C}$ & $5.5 \mathrm{~B}$ & $8.3 \mathrm{AB}$ & $11.5 \mathrm{~A}$ & $8.4 \mathrm{AB}$ & $5.3 \mathrm{~B}$ & \\
\hline
\end{tabular}

Data were means of 15 shoots cultured at a density of 5 shoots per culture tube containing $6 \mathrm{ml}$ of liquid, half-strength MS medium enriched with IBA at $2.0 \mathrm{mg} / \mathrm{l}$.

Means of each rooting parameter followed by the same letters were not significantly different at $\mathrm{p} \leq 0.05$ according to Duncan Multiple Range Test.

In summary, no rooting was obtained in medium enriched with $5 \mathrm{~g} / 1$ no matter how long the shoots were incubated. None of the shoots in medium enriched with $10 \mathrm{~g} / 1$ produced roots during the first 30 days of incubation, and only a few shoots rooted after 45 and 60 days. However, all shoots rooted if the incubation extended to 75 days. The lowest root formation (1 root per shoot) and root elongation (1.7 $\mathrm{mm}$ long) obtained in medium enriched with sucrose at 10 $\mathrm{g} / \mathrm{l}$ and incubated for 45 and 60 days and the shortest plantlets $(15.7 \mathrm{~mm})$ obtained in medium enriched with sucrose at 5 and $10 \mathrm{~g} / 1$ for 30 days. The highest rooting percentage $(100 \%)$, the highest root formation (4.7 roots/shoot), root elongation $(27.3 \mathrm{~mm})$ and tallest plantlets $(46.3$ $\mathrm{mm})$ were all obtained after 75 days incubation but at different sucrose enrichment, 10, 20, 20 and $25 \mathrm{~g} / 1$ respectively.

\section{DISCUSSION}

Enrichment of medium with sucrose at $30 \mathrm{~g} / 1$ and incubation for 30 days which is the most common practice for in vitro rooting was not the proper treatment for Moris pineapple. It resulted in the rooting of only $33 \%$ of the shoots, and the plantlets were shorter than $25 \mathrm{~mm}$. At any fixed incubation period sucrose at 15, 20 and 25 $\mathrm{g} / \mathrm{l}$ were a better choice for rooting than sucrose at $30 \mathrm{~g} / 1$, and at any fixed sucrose content any incubation periods resulted in a better rooting response than the 30-day long incubation (Table 
2). Out of 24 combinations of sucrose concentrations and incubation periods, sucrose at $30 \mathrm{~g} / \mathrm{l}$ and incubation for 30 days resulted in lower a rooting percentage than 15 of the combinations, shorter plantlets than 13 , fewer roots than 8 , and shorter roots than 9 of the tested combinations. Incubation for 75 days was the best incubation period for all rooting parameters. However, each parameter had different optimal sucrose concentration. The tallest plantlets $(46.3 \mathrm{~mm})$ were obtained in medium enriched with sucrose at $25 \mathrm{~g} / 1$, the highest (4.7 roots) and the longest $(27.3 \mathrm{~mm})$ roots were obtained in medium enriched with sucrose at $20 \mathrm{~g} / 1$, while the highest rooting percentage $(100 \%)$ was obtained in medium enriched with sucrose at 10 and $20 \mathrm{~g} / \mathrm{l}$. Not only at each incubation period different rooting parameters had different optimum sucrose, but also the same rooting parameter had different optimum sucrose at different incubation periods. The best sucrose concentration for the highest rooting percentage of shoots incubated for $30,45,60$, and 75 days was $25,15,20$, and $10 \mathrm{~g} / 1$ respectively. On the contrary, the best sucrose concentration for plantlet height of the shoot incubated for 30 , 45,60 and 75 days was $10,15,20$, and $25 \mathrm{~g} / 1$ respectively. The optimum sucrose concentration for root formation (root number) and root elongation (root length) if shoots were incubated for 30,45 , and 60 days was $15 \mathrm{~g} / 1$, and if shoots were incubated for 75 days was $20 \mathrm{~g} / 1$.

Since different rooting parameters have different optimum combinations of sucrose and incubation periods, different combinations could be recommended depending on whether one, two, or all of the parameters were used for assessment. For obtaining over $90 \%$ rooting and roots longer than $10 \mathrm{~mm}$, the choice would be between sucrose at $10 \mathrm{~g} / 1$ and incubation for 75 days and sucrose at $15 \mathrm{~g} / 1$ and incubation for 60 days. For the formation of more than three roots per shoot, the choice is sucrose at $10 \mathrm{~g} / \mathrm{l}$ and incubation for 75 days and sucrose at 15 and incubation for 30 days. Plantlets obtained after 45 days of incubation in medium enriched with sucrose at 15 and $20 \mathrm{~g} / 1$ and after 60 and 75 days of incubation irrespective of sucrose enrichment were taller than $35 \mathrm{~mm}$. Sucrose at $15 \mathrm{~g} / 1$ and incubation for 45 days and sucrose at $10 \mathrm{~g} / \mathrm{l}$ and incubation for 60 days was the best compromise for lowest sucrose and shortest incubation in which plantlets were taller than $35 \mathrm{~mm}$. The combination of sucrose and incubation for lowest cost of rooting (Table, 3) appears to be one of the following: the low sucrose level of $10 \mathrm{~g} / \mathrm{l}$ but longer incubation of 75 days, intermediate sucrose of 15 $\mathrm{g} / 1$ and shortest incubation of 45 days and high sucrose of $20 \mathrm{~g} / \mathrm{l}$ and intermediate incubation of 60 days. Low sucrose reduces the sucrose cost, but long incubation increases the monthly electricity bill. Selection among these alternatives would depend on the cost of each added or saved $5 \mathrm{~g} / \mathrm{l}$ of sucrose and the electricity bill of each increase or decrease of 15 days of incubation according to the price prevailed in the district at which the propagation takes place. The calculation of cost (Table, 3) showed that the cost of rooting was mainly due to incubation periods more than the concentration of sucrose. At a density of 5 shoots per culture, the minimum rooting cost per shoot was 3.95 cents, obtained when the shortest incubation (30 days) and lowest sucrose $(5 \mathrm{~g} / \mathrm{l})$ was applied while the highest cost was 5.88 cents when the longest incubation (75 days) and highest sucrose ( $30 \mathrm{~g} / \mathrm{l})$ was applied. At any incubation period, the difference in rooting cost per shoot at different sucrose concentrations was negligible (less than 0.02 cents), while incubation of 30 days decreased the cost by 2 cents compared to 75 days of incubation. In a previous report, we estimated the multiplication cost per shoot after 4 cycles of multiplication to be 0.9 (Hamad, 2017a) and if one liter of medium was used, to be 1.6 (Hamad, 2017b) cents. This study showed that the rooting cost per shoot (rooting stage) ranges from 3.95 to 5.88 cents, which is 2 to 6 times the multiplication cost per shoot (multiplication stage). Hence, to efficiently minimize the cost of micropropagation, the effort should be concentrated on reducing the cost of rooting rather than the cost of multiplication. Otherwise, the complaints about the high cost of micropropagated materials would always be there even if the 
multiplication was fully automated and at the highest rate.

Table (3). Effect of incubation periods and sucrose concentrations on the rooting cost per shoot of Moris pineapple

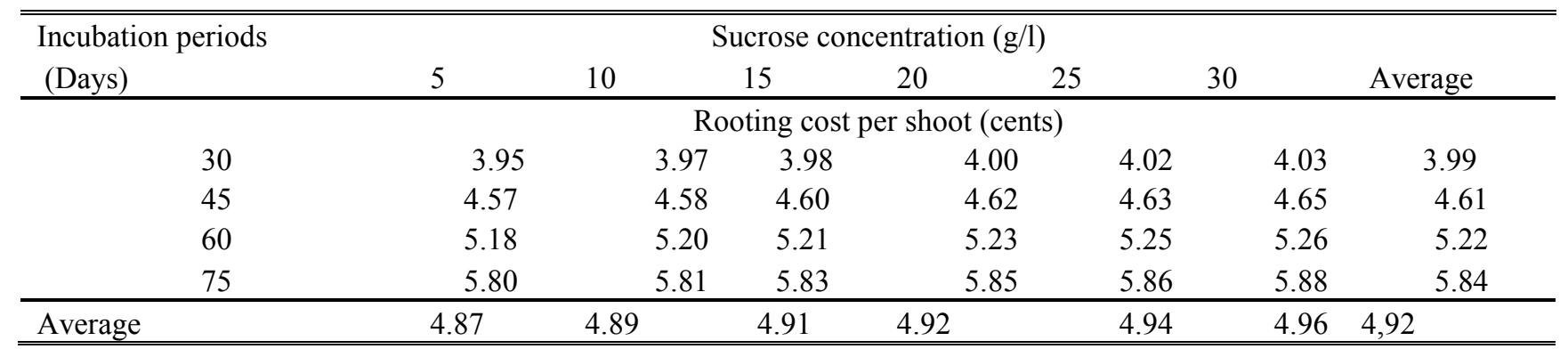

Mediums were prepared in glass jars, autoclaved at $121^{\circ} \mathrm{C}$ and $1.5 \mathrm{~kg} / \mathrm{cm}^{2}$ for 20 minutes and dispensed into culture tubes under a laminar cabinet. Shoots were rooted at a density of 5 shoots per culture tubes containing $6 \mathrm{ml}$ of liquid half-strength MS medium enriched with IBA at $2.0 \mathrm{mg} / \mathrm{l}$. and incubated under constant temperature $\left(25^{\circ} \mathrm{C}\right.$ and 16 hours of light provided by cool white fluorescent lamps.

The selection of the best combination of incubation and sucrose should depend on whether the purpose of the experiment would be the reduction of propagation cost and obtaining plantlets that could survive acclimatization or physiological study of rooting. Minimum sucrose and shorter incubation which result in plantlet quality above that required for highest acclimatization survival are very important for low-cost micropropagation, while the determination of the time at which rooting takes place, and monitoring of increase in root number and length, and plantlet height over time, are important for the physiological study of roots and proper timing of histological and physiobiochemical analysis. Published studies did not elaborate on the relationship between rooting percentage, root per shoot and root length, and plantlet survival. It is not known which one or two of these parameters are very crucial for the survival of acclimatization. (Escalona et al., 1999) reported that the survival percentage of ex vitro acclimatized rootless shoots increased from 20 to $100 \%$ as the size of the shoots increased from 20 to 80 mm long. (Be \& Debergh, 2006; Dal Vesco et al., 2001; DeWald et al., 1988; Ko et al., 2006; Soneji et al., 2002a) respectively reported that over $90 \%$ of $35,50,60,70$ and $80 \mathrm{~mm}$ longrooted pineapple shoots survived the acclimatization stage. For pineapple, plantlet height is probably more crucial for acclimatization survival. Therefore, the selection should be for a combination of sucrose and an incubation period that re- sults in plantlets taller than the minimum required height $(35 \mathrm{~mm})$ for survival at the lowest cost. If plantlets taller than $35 \mathrm{~mm}$ are suitable for successful acclimatization, there will be two combinations of sucrose and incubation period (sucrose at $15 \mathrm{~g} / 1$ and 60 days and sucrose at $15 \mathrm{~g} / 1$ and 75 days) to choose from.

But if the plantlet has to be taller than $40 \mathrm{~mm}$, sucrose at $15 \mathrm{~g} / \mathrm{l}$ and incubation for 75 days is the cheapest combination. In this study, all of the plantlets obtained after each incubation, irrespective of sucrose enrichments and its rooting response, were used for acclimatization. Following Hamad, (2016) recommendation, plantlets were placed in pots full of sand under a polyethylene enclosure for 21 days and a shade house for 60 days. The survival of plantlets that were rooted for $30,45,60$ and 75 days was $70.0 ; 80.5 ; 84.5$, and $94.3 \%$ respectively. Some of the plantlets of the 30 days incubation were rootless, and some were with fewer and shorter roots and the plantlets were less than 35 $\mathrm{mm}$ in height. The low survival of these plantlets $(70 \%)$ may be due to one or more of these rooting parameters. If the survival of acclimatization is not of major interest, as in the case of physiological study of rooting, different sucrose enrichment has to be used at different incubation periods depending on which parameter was of major interest. After 45 days incubation, sucrose at $15 \mathrm{~g} / 1$, and after 60 days of incubation, sucrose at $20 \mathrm{~g} / 1$ was the best enrichment for obtaining taller plantlets, highest rooting percentage and 
more and longest roots while after 30 and 75 days of incubation, three sucrose enrichments could be used depending on the parameter of major interest. In the case of 30 days incubation, sucrose at $10 \mathrm{~g} / 1$ for tallest plantlet, sucrose at $25 \mathrm{~g} / 1$ for highest rooting percentage, sucrose at $15 \mathrm{~g} / 1$ for more and longer roots, while in the case of 75 days incubation, sucrose at $25 \mathrm{~g} / 1$ for tallest plantlets, sucrose at $10 \mathrm{~g} / 1$ for highest rooting percentage and sucrose at $20 \mathrm{~g} / 1$ for more and longer roots.

The optimum sucrose for rooting percentage under $30,45,60$, and 75 days of incubation was 25 , 15, 20 and $10 \mathrm{~g} / 1$ (Table, 2). On the contrary, the optimum sucrose for plantlet height under 30, 45, 60 , and 75 days of incubation was $10,15,20$, and $25 \mathrm{~g} / \mathrm{l}$. This means that high sucrose enrichments improved shoot rooting (rooting percentage) under a short incubation regime but retarded the shoot growth (plantlet height). While under a long incubation regime they retarded shoot rooting but improved shoot growth. This indicated that the two processes of root initiation and plantlet elongation did not occur simultaneously, but one of them followed the other. Under low sucrose enrichment, the shoot directed the sucrose use for shoot growth and then for root initiation, and under high sucrose enrichment, the shoot directed the sucrose use first for root initiation and then for shoot growth. Both of the two parameters increased as the incubation periods increase up to 75 days, but the time at which most shoots rooted and the highest increase in plantlet height occurred varied over each 15 day period among the different combinations of incubation period and sucrose concentration. Being that no rooting occurred in medium enriched with $5 \mathrm{~g} / 1$ even if the incubation period increased to 75 days while the plantlet height reached $24 \mathrm{~mm}$ tall indicated that initiation of the rooting process in the presence of $5 \mathrm{~g} / \mathrm{l}$ requires shoots longer than $24 \mathrm{~mm}$. Failure of shoots to form roots for the first 30 days in medium enriched with sucrose at $10 \mathrm{~g} / \mathrm{l}$ while $75 \%$ of shoots form roots in the period between 60 and 75 days indicated that the shoot length limit for rooting in the presence of sucrose at $10 \mathrm{~g} / \mathrm{l}$ is $35 \mathrm{~mm}$ long shoots. Noticing the peri- od at which $50 \%$ of the shoots rooted indicated that the required shoot length for rooting in medium enriched with 15,20 , and $20 \mathrm{~g} / 1$ was 22 $\mathrm{mm}$. Similarly, it can be noticed that the required shoot length for rooting of over $75 \%$ of shoots in medium enriched with 10, 15, 20, 25, and $30 \mathrm{~g} / 1$ was $35,32,37,30$, and $42 \mathrm{~mm}$ respectively. It seemed that the rooting started after the shoots attain a certain size, and the sucrose is not involved in rooting directly, but by enhancing the shoot to reach the size required for the shoot to gain root forming ability.

Sucrose was involved in controlling the time at which the root initiation occurred and also the pattern of root formation and elongation over time. In medium enriched with sucrose at $5 \mathrm{~g} / \mathrm{l}$, the shoots failed to root even if the incubation extended to 75 days. In medium enriched with sucrose at $10 \mathrm{~g} / \mathrm{l}$, no rooting occurred in the first 30 days and only $25 \%$ rooted in the first 60 days of incubation, but all of the shoots rooted when the incubation extended to 75 days. That is, $75 \%$ of rooting occurred in the last 15 days of incubation. Incubation shorter than 75 days will result in poor rooting. On the contrary, in medium enriched with sucrose at $15 \mathrm{~g} / 1,75 \%$ of rooting occurred within the first 45 days of incubation, no rooting occurred in the period between 45 and 60 days and only $17 \%$ rooted in the period between 60 and 75 days of incubation. Under this sucrose enrichment, incubation should be terminated after 45 days. In medium enriched with sucrose at 20 and $25 \mathrm{~g} / 1,92 \%$ of shoots rooted within the first 60 days and only $8 \%$ rooted in the period between 60 and 75 days of incubation. In medium enriched with sucrose at $30 \mathrm{~g} / 1,67 \%$ of shoots rooted in 60 days, $8 \%$ in the period between 60 and 75 days, and $25 \%$ of the shoots failed to root even if the incubation extended to 75 days. That is if the medium is enriched with sucrose at 20, 25 , and $30 \mathrm{~g} / \mathrm{l}$ the incubation should be terminated after 60 days of incubation.

Similarly, depending on sucrose enrichment, the process of root formation (root number), and elongation (root length) ranged from did not start, stopped after 30,45 or 60 , days to be a continu- 
ous process for 75 days. In medium enriched with sucrose at $10 \mathrm{~g} / \mathrm{l}$, no root formation occurred in the first month and most of the roots occurred in the last 15 days of the 75 days incubation (60 to 75 days). On the contrary, in medium enriched with sucrose at $30 \mathrm{~g} / 1$, shoot rooting occurred in the first month and no root formed after that even if the incubation extended to 75 days. In medium enriched with sucrose at 15 and $25 \mathrm{~g} / \mathrm{l}$, root formation occurred in alternative cycles. Root formation occurred in the first month of incubation and the period between 45 - 60 days, and no formation occurred in the period between 30- 45 and 60- 75 days of incubation. In medium enriched with sucrose at $20 \mathrm{~g} / \mathrm{l}$, root formation was a non-stop continuous process of alternative slow and fast root growth over 75 days of incubation. Similarly, root elongation was also a continuous non-stop process for 75 days in medium enriched with 10 and $20 \mathrm{~g} / 1$. However, in medium enriched with sucrose at 15,25 , and $30 \mathrm{~g} / 1$ no root elongation occurred after 60 days of incubation. Daily and weekly records of the changes in rooting parameters would determine the time of fast, slow and no growth, and the best time for histological and biochemical analysis.

Although the weight and length of the shoots used during rooting were not taken into consideration,(Ramirez-Malagon et al., 2001) found that heavy shoots of Spathiphyllum floribundum obtained during multiplication had a higher chance of survival during acclimatization. Hamad (2017c) found that the period of the highest increase in shoot weight and length of Smooth cayenne pineapple over each 15 days of 105 days of incubation varied depending on the hormone treatments and occurred after the shoots incubated for more than 45 days. Weight, length, and density of shoots at the beginning of the rooting stage may have great influence in its rooting response to sucrose and incubation period and proposed for future testing. (Hamad et al., 2013) found that the different rooting parameters of Moris pineapple had different optimum hormone type and concentration and medium strength and the rooting percentage ranged from 30 to $100 \%$, root number from 1 to 10 roots, root length from
5 to $65 \mathrm{~mm}$ and plantlet height from 19 to 65 $\mathrm{mm}$. For taller plantlets they recommended the use of IBA at $0.5 \mathrm{mg} / 1$ in quarter strength solid $\mathrm{MS}$ and IAA at $2.5 \mathrm{mg} / 1$ in full strength liquid MS. Quarter strength MS and IAA at $2.5 \mathrm{mg} / \mathrm{l}$ is suggested for future testing in combination with shoots of different length and density under different photoperiods at 5, 10 and 15 grams of sucrose per liter of medium over 30 and 45 days of incubation. Such testing may come up with a treatment that overcomes the no rooting in medium enriched with sucrose at $5 \mathrm{~g} / 1$ and incubated for 30 days, or shorten the incubation in medium enriched with sucrose at $10 \mathrm{~g} / 1$ from 75 to 30 days and would reduce the cost and result in plantlets with the quality required for survival of acclimatization.

\section{REFERENCES}

Almeida, W., De Matos A., and Souza A. d. S. (1997). Effects of benzylaminopurine (BAP) on in vitro proliferation of pineapple (Ananas comosus (L.) Merr.). Pages 235-242 in II International Pineapple Symposium 425.

Almeida, W. A. B. D., Santana, G. S., Rodriguez, A. P., \& Costa, M. A. P. D. C. (2002). Optimization of a protocol for the micropropagation of pineapple. Revista Brasileira de Fruticultura, 24(2), 296-300.

Amin, M., Rahman, M., Rahman, K., Ahmed, R., Hossain, M., \& Ahmed, M. (2005). Large Scale Plant Regeneration in vitro from Leaf Derived Callus Cultures of Pineapple [Ammas comosus (L.) Merr. cv. Giant Kew].

Aydieh, A., Ibrahim, M., \& Ibrahim, A. (2000). In vitro propagation and fruiting of pineapple. Egyptian Journal of Horticulture, 27(3), 289-304.

Be, L., \& Debergh, P. (2006). Potential lowcost micropropagation of pineapple 
(Ananas comosus). South African Journal of Botany, 72(2), 191-194.

Bhatia, P., \& Ashwath, N. (2000). Development of a rapid method for micropropagation of a new pineapple [Ananas comosus (1.) Murr.] clone,'Yeppoon gold'. International Symposium on Tropical and Subtropical Fruits 575,

Dal Vesco, L. L., de Almeida Pinto, A., Zaffari, G. R., Nodari, R. O., dos Reis, M. S., \& Guerra, M. P. (2001). Improving pineapple micropropagation protocol through explant size and medium composition manipulation. Fruits, 56(3), 143-154.

Danso, K., Ayeh, K., Oduro, V., Amiteye, S., \& Amoatey, H. (2008). Effect of 6benzylaminopurine and naphthalene acetic acid on in vitro production of MD2 pineapple planting materials. World Applied Sciences Journal, 3(4), 614-619.

De Almeida, W., De Matos, A., \& Souza, A. d. S. (1997). Effects of benzylaminopurine (BAP) on in vitro proliferation of pineapple (Ananas comosus (L.) Merr.). II International Pineapple Symposium 425 ,

DeWald, M., Moore, G., Sherman, W., \& Evans, M. (1988). Production of pineapple plants in vitro. Plant cell reports, 7(7), 535-537.

Escalona, M., Lorenzo, J., González, B., Daquinta, M., González, J., Desjardins, Y., \& Borroto, C. (1999). Pineapple (Ananas comosus L. Merr) micropropagation in temporary immersion systems. Plant cell reports, 18(9), 743-748.

Fitchet, M. (1990). Clonal propagation of Queen and Smooth Cayenne pineapples. International Symposium on the Culture of Subtropical and Tropical Fruits and Crops 275,

Gangopadhyay, G., Bandyopadhyay, T., Poddar, R., Gangopadhyay, S. B., \& Mukherjee, K. K. (2005). Encapsulation of pineapple micro shoots in alginate beads for temporary storage. Current Science, 972-977.

Hamad, A. M. (2016). Effect of peatmoss and sand mixing ratio on the acclimatization of Smooth cayenne pineapple (Ananas comosus (L) Merr.). J. of Science and Humanities, 22: 1-6.

Hamad, A. M. (2017a). Effect of incubation periods, medium volumes and explants density on the in vitro shoot formation and growth and cost of multiplication of Moris pineapple. El Mukhtar J. of Sciences, 33 (1): 10 -16.

Hamad, A. M. (2017b). Effect of explants density, medium volumes and subcultures on the in vitro shoot formation and cost of multiplication of Moris pineapple (Ananas comosus L. Merr). Libyan J of Basic Sciences 7 (1): 78- 90 .

Hamad, A. M. (2017c). Biweekly changes in the in vitro shoot formation and growth pattern of pineapple (Ananas comosus L Merr) cv Smooth cayenne over 105 days of incubation on different hormone treatments. Globial Libyan J. 18: $1-17$

Hamad, A. M., and Taha R. M. (2008). Effect of sequential subcultures on in vitro proliferation capacity and shoot formations pattern of pineapple (Ananas comosus L. Merr.) over different incubation periods. Scientia Horticulturae 117(4):329-334.

Hamad, A. M., Taha R. M., and Mohajer S. (2013). In vitro induction and proliferation of adventitious roots in 
pineapple (Ananas comosus L.) cultivars of smooth cayenne and morris. Australian Journal of Crop Science 7(7):1038-1045.

Hamad, A. H. M., Taha, R. M., \& Mohajer, S. (2013). In vitro induction and proliferation of adventitious roots in pineapple (Ananas comosus L.) cultivars of smooth cayenne and morris. Australian Journal of Crop Science, 7(7), 1038-1045.

Hamad, A. M., \& Taha, R. M. (2008). Effect of sequential subcultures on in vitro proliferation capacity and shoot formations pattern of pineapple (Ananas comosus L. Merr.) over different incubation periods. Scientia Horticulturae, 117(4), 329-334.

Khan, S., Nasib A., and Saeed B. A. (2004). Employment of in vitro technology for large scale multiplication of pineapples (Ananas comosos). Pakistan Journal of Botany 36(3):611-616.

Khatun, M., Khanam D., Hoque M., and Quasem A. (1997). Clonal propagation of pineapple through tissue culture. Plant Tissue Cult 7(2):143-148.

Ko, H., Campbell P., Jobin-Décor M., Eccleston K., Graham M., and Smith M. (2006). The introduction of transgenes to control blackheart in pineapple (Ananas comosus L.) cv. Smooth Cayenne by microprojectile bombardment. Euphytica 150(3):387.

Kofi, O., and Adachi T. (1993). Effect of cytokinins on the proliferation of multiple shoots of pineapple in vitro. SABRAO Journal 25(1):59-69.

Mathews, V. H., and Rangan T. (1979). Multiple plantlets in lateral bud and leaf explant in vitro cultures of pineapple. Scientia Horticulturae 11(4):319-328.
Mathews, V. H., and Rangan T. (1981). Growth and regeneration of plantlets in callus cultures of pineapple. Scientia Horticulturae 14(3):227-234.

Mengesha, A., Ayenew B., and Tadesse T. (2013). Energy sources affect in vitro propagation and subsequent acclimatization of Ananas comosus, var. smooth cayenne plants. The Journal of Microbiology, Biotechnology and Food Sciences 2(6):2372

Murashige, T. and F. Skoog. 1962. A revised medium for rapid growth and bioassay with tobacco tissue. Physiol. Plan/ 1962, 15: 473- 497

Ramirez-Malagon, R., Borodanenko A., Barrera-Guerra J. L., and Ochoa-Alejo N. (2001). Shoot number and shoot size as affected by growth regulators in in vitro cultures of Spathiphyllum floribundum L. Scientia Horticulturae 89(3):227-236.

Singh, D., and Manual A. (2000). Assessment of pineapple plants developed from micropropagation instead of conventional suckering. Tropical Science 40(4):169-173.

Soneji, J. R., Rao P., and Mhatre M. (2002a). In vitro Regeneration from Leaf Explants of Pineapple (Ananas comosus L, Merr). Journal of plant biochemistry and biotechnology 11(2):117-119.

Soneji, J. R., Rao P., and Mhatre M. (2002b). Somaclonal variation in micropropagated dormant axillary buds of pineapple (Ananas comosus L., Merr.). The Journal of Horticultural Science and Biotechnology 77(1):2832 .

Souza, F. V. D., Da Silva M. D. J., Souza A. D. S., and Costa M. A. P. D. C. (2016). Growth regulators and physical state of 
culture media in the micropropagation of ornamental pineapple hybrids. Plant Cell Culture \& Micropropagation 8(12):10-17.

Sripaoraya, S., Marchant R., Brian Power J., and Davey M. R. (2003). Plant regeneration by somatic embryogenesis and organogenesis in commercial pineapple (Ananas comosus L.). In Vitro Cellular and Developmental Biology-Plant 39(5):450-454.

Sunitibala Devi, Y., Mujib A., and Kundu S. (1997). Efficient regenerative potential from long term culture of pineapple. Phytomorphology 47(3):255-259.

Teng, W.-L. (1997). An alternative propagation method ofAnanas through nodule culture. Plant cell reports 16(7):454457.

Khan, S., Nasib, A., \& Saeed, B. A. (2004). Employment of in vitro technology for large scale multiplication of pineapples (Ananas comosos). Pakistan Journal of Botany, 36(3), 611-616.

Khatun, M., Khanam, D., Hoque, M., \& Quasem, A. (1997). Clonal propagation of pineapple through tissue culture. Plant Tissue Cult, 7(2), 143-148.

Ko, H., Campbell, P., Jobin-Décor, M., Eccleston, K., Graham, M., \& Smith, M. (2006). The introduction of transgenes to control blackheart in pineapple (Ananas comosus L.) cv. Smooth Cayenne by microprojectile bombardment. Euphytica, 150(3), 387.

Kofi, O., \& Adachi, T. (1993). Effect of cytokinins on the proliferation of multiple shoots of pineapple in vitro. SABRAO Journal, 25(1), 59-69.

Mathews, V. H., \& Rangan, T. (1979). Multiple plantlets in lateral bud and leaf explant in vitro cultures of pineapple. Scientia Horticulturae, 11(4), 319-328.

Mathews, V. H., \& Rangan, T. (1981). Growth and regeneration of plantlets in callus cultures of pineapple. Scientia Horticulturae, 14(3), 227-234.

Mengesha, A., Ayenew, B., \& Tadesse, T. (2013). Energy sources affect in vitro propagation and subsequent acclimatization of Ananas comosus, var. smooth cayenne plants. The Journal of Microbiology, Biotechnology and Food Sciences, 2(6), 2372.

Ramirez-Malagon, R., Borodanenko, A., Barrera-Guerra, J. L., \& Ochoa-Alejo, N. (2001). Shoot number and shoot size as affected by growth regulators in in vitro cultures of Spathiphyllum floribundum L. Scientia Horticulturae, 89(3), 227-236.

Singh, D., \& Manual, A. (2000). Assessment of pineapple plants developed from micropropagation instead of conventional suckering. Tropical Science, 40(4), 169-173.

Soneji, J. R., Rao, P., \& Mhatre, M. (2002a). In vitro Regeneration from Leaf Explants of Pineapple (Ananas comosus L, Merr). Journal of plant biochemistry and biotechnology, 11(2), 117-119.

Soneji, J. R., Rao, P., \& Mhatre, M. (2002b). Somaclonal variation in micropropagated dormant axillary buds of pineapple (Ananas comosus L., Merr.). The Journal of Horticultural Science and Biotechnology, 77(1), 2832.

Souza, F. V. D., Da Silva, M. D. J., Souza, A. D. S., \& Costa, M. A. P. D. C. (2016). Growth regulators and physical state of culture media in the micropropagation of ornamental pineapple hybrids. Plant 
Cell Culture \& Micropropagation, 8(12), 10-17.

Sripaoraya, S., Marchant, R., Brian Power, J., \& Davey, M. R. (2003). Plant regeneration by somatic embryogenesis and organogenesis in commercial pineapple (Ananas comosus L.). In Vitro Cellular and Developmental Biology-Plant, 39(5), 450-454.

Sunitibala Devi, Y., Mujib, A., \& Kundu, S. (1997). Efficient regenerative potential from long term culture of pineapple. Phytomorphology, 47(3), 255-259.

Teng, W.-L. (1997). An alternative propagation method ofAnanas through nodule culture. Plant cell reports, 16(7), 454457. 


\title{
تأثير تركيزات السكروز وطول فترة التحضين على تجذير الأناناس صنف Moris (أناناس كوموسوس) مخبرياً
}

\author{
عبد الحميد مختار حمد \\ قسم البستنه، كلية الزراعة، جامعة عمر المختار، البيضاء كبيبيا
}

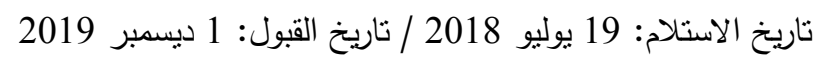
https://doi.org/10.54172/mjsc.v34i4.145:Doi

المستخلص: اختبر تأثثر ستة تركيزات من السكروز (5، 10، 15، 20، 25 و 30 جرام/لتر) وأربع فترات تحضين (30،

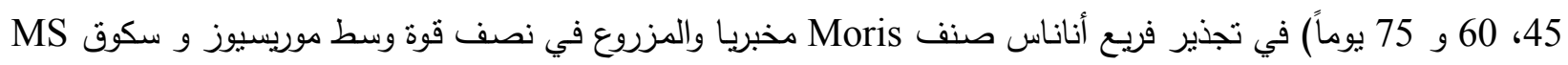

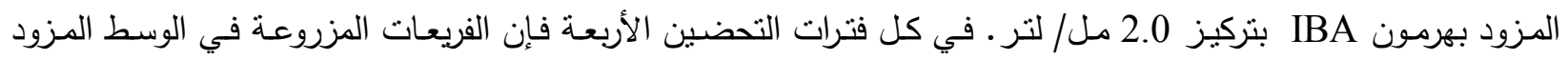

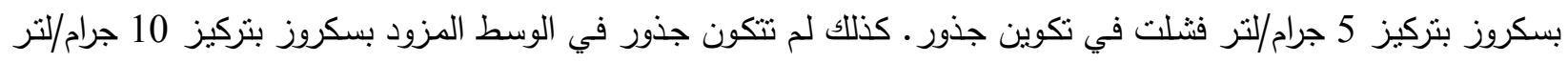

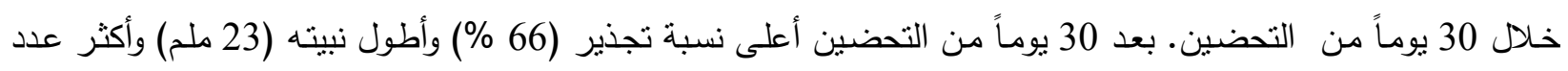

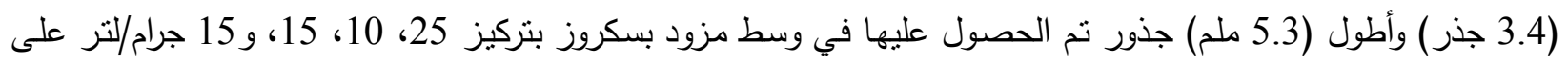

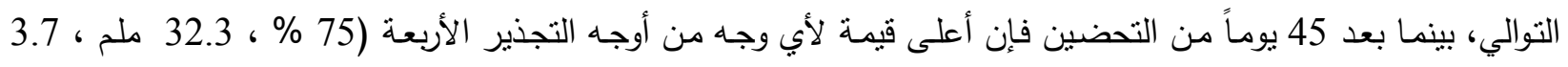

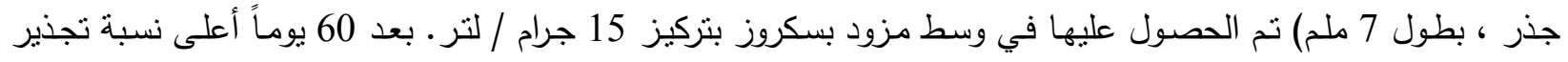

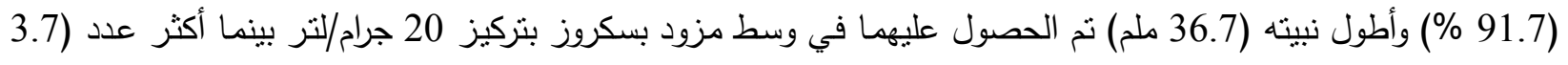

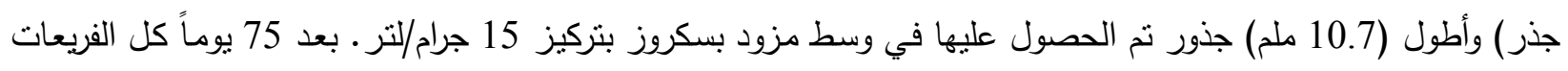

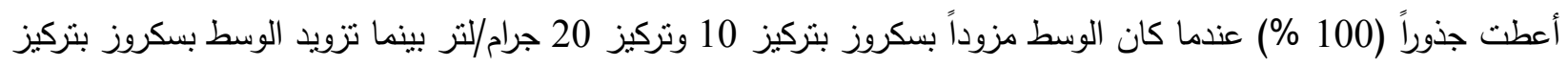

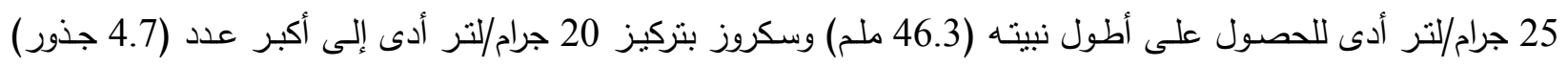
وأطول (27.3 ملم) جذور • عند كل طول فترة تحضين هناك تركيز مثالي مختلف من السكروز لكل وجه من أوجه التجذير المختلفة. الكلمات المفتاحية: سكروز ، فترة التحضين، التجذير مخبرياً، الأناناس، أناناس كوموسوس. 